\title{
INFLUENCE OF BENZYLADENINE AND KRISTALON FERTILIZER TREATMENTS ON GROWTH AND CHEMICAL CONSTITUENTS OF LEMON CYPRESS (CUPRESSUS MACROCARPA L.) PLANT
}

\author{
Y.A.A. Ghatas \\ Horticulture Department, Faculty of Agriculture, Benha University, Egypt
}

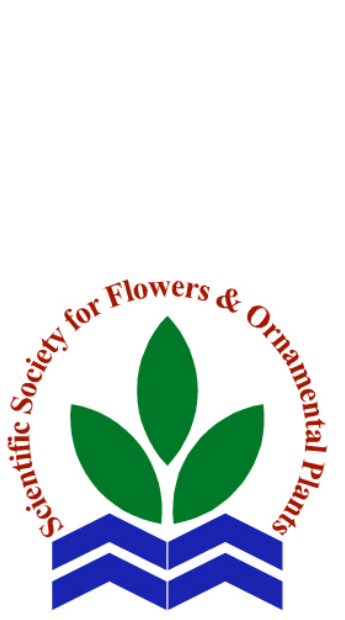

\begin{abstract}
A pot experimental trial was carried out during 2017 and 2018 seasons, to study the effect of 16 treatments, which were represented by the combinations between four concentrations of benzyladenine (BA), i.e. 0, 50, 75 and $100 \mathrm{ppm}$ and kristalon fertilizer rates at $0,3,5$ and $7 \mathrm{~g} /$ pot on the growth and chemical constituents of Cupressus macrocarpa plant. Results declared that all tested concentrations of BA increased plant height, No. of branches/plant, stem diameter, fresh, dry weights of shoots/plant, fresh, dry weights of roots/plant, as well as chemical constituents parameters i.e. N, P and K in the leaves, total carbohydrates, total chlorophylls and carotenoids contents, with an evident for the high rates of benzyladenine compared to untreated control plants in both seasons. On the other hand, all levels of kristalon chemical fertilizer significantly enhanced all the parameters in the two seasons, particularly using the combinations between BA at $100 \mathrm{ppm}$ and kristalon fertilizer at $7 \mathrm{~g} / \mathrm{pot}$ in both seasons. Conclusively, spraying Cupressus macrocarpa plant with benzyladenin at $100 \mathrm{ppm}$ and supplemented with kristalon as chemical fertilizer at $7 \mathrm{~g} /$ pot produced the best growth and quality of Cupressus macrocarpa L. plant.
\end{abstract} Scientific J. Flowers \& above-mentioned parameters, especially using the high level at $7 \mathrm{~g} / \mathrm{pot}$ Ornamental Plants, in both seasons. In addition, most of the applied combinations of 7(3):221-237 (2020). benzyladenine and levels of kristalon fertilizer improved all the studied

Received:

20/7/2020

Accepted:

$17 / 8 / 2020$

Key words: Cupressus macrocarpa, lemon cypress, BA, kristalon fertilizer, growth and chemical constituents.

\section{INTRODUCTION}

Cupressus macrocarpa cv. Goldcrest is an evergreen ornamental tree and belongs to the family Cupressaceae. It is known as lemon cypress or monterey cypress, while native to California on a large scale, it is spread in warm temperatures and in tropical regions around the world (Hogan and Frankis, 2009). Lemon cypress (Cupressus macrocarpa) is a handsome pot plant used widely. It is narrow in a pyramidal shape, especially, when it is small and its leaves are sharp in length up to $2-5 \mathrm{~mm}$, and it is distinguished by its bright green color, it grows intensively and releases a deep lemon scent, especially when crushed. Also, the tree grows well in temperate climates and needs well-drained lands and endures high levels of drought and maritime exposure, it is able to face many unwanted changes during its growth stages (Gut, 2008; Graf, 1992 and Thukral et al., 2014). Lemon cypress is considered one of the beautiful trees in the shape and desirable in Egypt, where it has a role in the field of landscape, especially in the tourist villages and coastal areas as it spreads in the gardens of the new cities because of its wonderful pyramidal shape and golden foliage, it is always planted individually specimen, as hedge or as potted plants, so the demand for this tree is great. 


\section{Y.A.A. Ghatas}

With all this, the monterey cypress trees are very slow growing, especially in the seedling stage, so nursery growers are waiting for a long period of up to several months to reach commercial production of the appropriate size and required for marketing. Thus, the available plants are not sufficient for the various landscape practices. Growth regulators work to increase plant growth and development, as they enter into many physiological processes within the plant and stimulate the work of enzymes and the formation of amino acids and promote growth in all different stages and thus increase plant productivity (Buban, 2000). The use of growth regulators in their various groups is important at the level of the world in the field of plant cultivation in general and ornamental plants because of its great impact on the growth of these plants and the improvement of their various characteristics. Where, it was found that the foliar spray of different growth regulators had a clear effect on the characteristics of the growth of floriculture plants and the improvement of their quality characteristics (Sajjad et al., 2017). Cytokinins are a group of other plant growth regulators, including naturally produced in plant or manufactured. Benzyladenine (BA) is the first-generation synthetic cytokinin, it has many effects including increase cell division, organogenesis differentiation, enhancement of leaf expansion, nutrient mobilization, inhibition of apical dominant, and stimulate the lateral buds to develop into an entire new plant, thus increasing the growth and division of the plant, which in turn reflects on the general state of plant growth and improving its productivity (Taiz and Zeiger, 2002 and Salisbury and Ross, 1974). Benzyladenine is known to have a great ability to divide cells and increase growth, as it can overcome the apical dominance in the plant and works to delay senescence and transfer of many dissolved substances from older parts of the leaves or older leaves into the treated zone (Hopkins and Huner, 2008). The effect of benzyladenine (BA) on the plant growth and chemical composition have demonstrated by Ali et al. (2018) on false aralia plants, Ibrahim et al. (2010) on croton plants, Sajjad et al. (2015) on Gladiolus grandiflorus, Youssef and Mady (2013) on Aspidistra elatior, Hegazy (2000) on gladiolus plants, Vijaykumari (2002) on Andrographis panculata. Abd $\mathrm{Al}$ Lateef and Hade (2018) mentioned that using BA at 30 $\mathrm{mg} \mathrm{l}^{-1}$ improved all vegetative growth parameters of Viola Tricolor. Also, El-Malt et al. (2006) on Hippeastrum vittatum plants mentiond that using benzyladenine at 20 ppm gave the best vegetative growth, flowering, and chemical constituents.

Chemical fertilization greatly affects the growth and productivity of plants in general, especially ornamental plants. Mineral fertilization plays a large role in improving and increasing vegetative growth and growth in general within the plant in particular with the optimal use rate. Many studies presented by many researchers studied examined different effects for chemical fertilizers on different plants have shown that they have a positive effect on increasing plant growth (Lumis et al., 2000 and El-Naggar et al., 2016). Also, the goal of adding fertilizers is to work on their presence to keep plants as they replace the nutrients that have been depleted in the soil and thus, we guarantee the availability of nutrients that the plant needs and helps it to grow (Younis et al., 2011). Chemical fertilization of plants leads to increased growth of plants in a large way and work to grow and develop with great speed and high efficiency, as it provides all the necessary and important raw materials inside the manufacturing plant, that the plant needs for the production line. Hence, fertilizing is very important for all plants, especially the ornamental plants growing in the pots. It is that in order for plants to grow well, they need many nutrients necessary for their growth. Nitrogen, phosphorus and potassium are the most important of these elements and most of the commercial and packed fertilizers contain these three nutrients due to their great importance for plant growth and production (Marschner, 1997). In this concern, Ghatas (2015) on 
Hemerocallis aurantiaca plant demonstrated that spraying with NPK chemical fertilizer at $6 \mathrm{~g} / \mathrm{l}$ gave the best vegetative growth, flowering and chemical composition. On the other side, Habib (2012) stated that treating Caryota mitis with $4 \mathrm{~g} / \mathrm{pot}$ of chemical fertilization gave the maximum results of plant height, stem diameter, number of leaves/plant, fresh and dry weight of shoots and roots, total chlorophylls and leaf $\mathrm{N}, \mathrm{P}$ and $\mathrm{K} \%$. In this concern, Youssef (2014) showed that adding kristalon chemical fertilizer (NPK) enhanced the vegetative growth parameters and photosynthetic pigments of Beaucarnea recurvate.

Consequently, this study was conducted to evaluate the effect of different concentrations of benzyladenine (BA) and kristalon chemical fertilizer treatments on growth and chemical composition of Cupressus macrocarpa L. plant.

\section{MATERIALS AND METHODS}

A pot experimental study was conducted at the Floriculture Nursery of the Horticulture Department, Faculty of Agriculture at Moshtohor, Benha University, during 2017 and 2018 seasons to study the effect of some different levels of benzyladenine (BA) and kristalon chemical fertilization treatments as well as their interactions on growth and chemical composition of Cupressus macrocarpa plant.

\section{Plant Material:}

Uniform of lemon cypress seedlings having 2-4 branches and 15-17 (cm) height were selected for achieving this study. The plants were obtained from Floriculture Nursery of the Horticulture Dept., Fac. of Agric., at Moshtohor, Benha Univ.

\section{Planting procedure:}

The plants were repotted in plastic pots of $30 \mathrm{~cm}$ diameter (one plant/pot), filled with medium contained sand : clay : compost mixture as $1: 1: 1$ by volume placed in a partial shade (12000-14000 lux light intensity) under lath house condition on $1^{\text {st }}$ March, in both seasons (2017 and 2018). The chemical characteristics of the planting medium were shown in Table (1). Chemical analysis were estimated according to Black et al. (1982).

Two factors were involved in the present study, the first was different concentrations of benzyladenine (BA) as foliar sprays and the second was chemical fertilization. The plants were subjected to foliar spray of BA at the concentrations of 0.0 (control), 50, 75 and $100 \mathrm{ppm}$ and sprayed six times at 20 days intervals, starting after one month from beginning the planting time at $1^{\text {st }}$ March, in both seasons. In addition to the control plants which sprayed with tap water. A surfactant (Tween 20) at a concentration of $0.01 \%$ was added to all sprayed solutions including the control. Common agricultural practices (irrigation, manual weed control, etc.) were conducted when needed.

\section{Fertilization treatments:}

Cupressus macrocarpa plants received the kristalon chemical fertilizer rates of 0,3 , 5 and 7 g/pot which were prepared and applied to the plants monthly interval as a dressing application for eight times, starting after one month from planting time in the

Table 1. Chemical analysis of the planting medium.

\begin{tabular}{lccc}
\hline \multicolumn{1}{c}{ Parameters } & Unit & $\mathbf{2 0 1 7}$ & Seasons \\
\hline CaCO $_{3}$ & $\%$ & 0.92 & $\mathbf{2 0 1 8}$ \\
Organic matter & $\%$ & 2.46 & 0.98 \\
Available nitrogen & $\%$ & 0.87 & 2.81 \\
Available phosphorus & $\%$ & 0.49 & 0.98 \\
Available potassium & $\%$ & 0.77 & 0.58 \\
E.C & $\mathrm{ds} / \mathrm{m}$ & 1.37 & 0.73 \\
$\mathbf{p H}$ & -- & $6 . .50$ & 1.22 \\
\hline
\end{tabular}


two seasons of this study. The kristalon chemical fertilizer NPK (20:20:20) was used. Kristalon fertilizer analysis: nitrogen 20\%, $\mathrm{P}_{2} \mathrm{O}_{5} 20 \%, \quad \mathrm{~K}_{2} \mathrm{O} 20 \%$, chelated zinc $0.0014 \%$, chelated iron $0.0070 \%$, chelated manganese $0.0042 \%$, chelated cupper $0.0016 \%$, chelated magnesium $0.0120 \%$, molybdenum $0.0014 \%$ and boron $0.0022 \%$.

\section{Experiment layout:}

The layout of the experiment was designed to provide a factorial experiment in randomized complete blocks. The study contained 16 treatments (4 rates of kristalon chemical fertilization $\times 4$ benzyladenine treatments) with three replicates, each replicate contained 5 pots. The experimental treatments were started in the two seasons at the first week of April.

\section{Data Recorded:}

On $30^{\text {th }}$ December in the two seasons, the experiment was finished and data recorded were:

\section{Vegetative growth parameters:}

a. Plant height (cm)

b. Number of branches/plant

c. Stem diameter $(\mathrm{cm})$

d. Fresh weight of shoots/plant (g)

e. Dry weight of shoots/plant (g)

\section{Root growth parameters:}

a. Fresh weight of roots/plant (g)

b. Dry weight of roots/plant (g)

\section{Chemical composition determination:}

Total nitrogen, phosphorus, potassium \% and total carbohydrates \% were determined in dried leaves according the methods described by Horneck and Miller (1998), Hucker and Catroux (1980), Horneck and Hanson (1998) and Herbert et al. (1971), respectively.

Total chlorophylls content as (mg/100 g F.W.), and carotenoids content (mg/g F.W.) were determined in fresh leaves according to A.O.A.C. (1990).

\section{Statistical analysis:}

All obtained data in both seasons of study were subjected to analysis of variance as factorial experiments in a complete randomized block design. L.S.D. method was used to differentiate between means according to Snedecor and Cochran (1989).

\section{RESULTS AND DISCUSSION}

\section{Vegetative growth measurements:}

Data obtained on vegetative growth measurements i.e. plant height, number of branches/plant, stem diameter, fresh and dry weights of shoots/plant (g) as affected by benzyladenine (BA) treatments i.e., $0.0 \mathrm{ppm}$ as control (tap water), $50 \mathrm{ppm}, 75 \mathrm{ppm}$ and $100 \mathrm{ppm}$ and kristalon chemical fertilizer $(0$, 3,5 and $7 \mathrm{~g} /$ pot) as well as their combinations are presented in Tables (2-4). Results declare that concerning the effect of the studied BA treatments on lemon cypress plant, it was interested to note that there was a positive relationship between vegetative growth measurement values and BA treatments in both seasons. Hence, as the concentration of BA increased, the values of the tested vegetative growth measurements augmented to reach its maximum with the high concentration, i.e. $100 \mathrm{ppm}$. Therefore, 100 ppm BA-sprayed plants statistically scored the highest values of plant height, number of branches/plant, stem diameter, fresh and dry weights of shoots/plant of lemon cypress plants in both seasons. In the same context, the concentration, of BA at 75 ppm, ranked the second in this respect compared to untreated control plants. On the other side, all different levels of chemical fertilization treatments succeeded in increasing the assigned vegetative measurements as compared with untreated control plants in both seasons. However, the highest records of all previous tested parameters were scored in lemon cypress plants treated with $7 \mathrm{~g} /$ pot in both seasons. As for the interaction effect between BA and kristalon treatments, it was evident that all applied combinations of chemical fertilizer and benzyladenine succeeded in increasing 
Table 2. Effect of benzyladenine (BA) and kristalon chemical fertilizer treatments on plant height, and branches number of Cupressus macrocarpa plants during 2017 and 2018 seasons.

\begin{tabular}{|c|c|c|c|c|c|c|c|c|c|c|}
\hline \multirow{3}{*}{ Fertilization treatments } & \multirow{2}{*}{\multicolumn{4}{|c|}{$\begin{array}{l}\text { Plant height (cm) } \\
\text { BA }\end{array}$}} & \multirow{2}{*}{\multicolumn{6}{|c|}{$\begin{array}{c}\text { Branches number/plant } \\
\text { BA }\end{array}$}} \\
\hline & & & & & & & & & & \\
\hline & 0.0 & $\begin{array}{c}50 \\
\text { ppm }\end{array}$ & $\begin{array}{c}75 \\
\text { ppm }\end{array}$ & $\begin{array}{c}100 \\
\text { ppm }\end{array}$ & Mean & 0.0 & $\begin{array}{c}25 \\
\text { ppm }\end{array}$ & $\begin{array}{c}75 \\
\text { ppm }\end{array}$ & $\begin{array}{c}100 \\
\text { ppm }\end{array}$ & Mean \\
\hline & \multicolumn{10}{|c|}{ First season: 2017} \\
\hline 0.0 & 47.11 & 48.16 & 50.82 & 53.55 & 49.91 & 18.22 & 19.33 & 21.55 & 27.55 & 21.66 \\
\hline 3 g/pot & 53.80 & 55.11 & 54.13 & 57.22 & 55.06 & 22.33 & 26.77 & 29.99 & 33.12 & 28.05 \\
\hline 5 g/pot & 58.21 & 63.33 & 67.66 & 71.55 & 65.18 & 28.16 & 31.71 & 33.66 & 36.16 & 32.42 \\
\hline 7 g/pot & 69.61 & 73.88 & 78.44 & 85.55 & 76.87 & 30.02 & 36.33 & 42.63 & 48.88 & 39.46 \\
\hline Mean & 57.18 & 60.12 & 62.76 & 66.96 & & 24.68 & 28.53 & 31.95 & 36.43 & \\
\hline \multicolumn{11}{|l|}{ LSD at $5 \%$ for: } \\
\hline BA & & & 2.14 & & & & & 3.12 & & \\
\hline Fertilization & & & 2.14 & & & & & 3.12 & & \\
\hline \multirow{2}{*}{ BA $\times$ fertilization } & & & 4.28 & & & & & 6.24 & & \\
\hline & \multicolumn{10}{|c|}{ Second season: 2018} \\
\hline 0.0 & 53.13 & 56.18 & 60.22 & 65.33 & 58.71 & 21.33 & 23.20 & 23.18 & 25.17 & 23.22 \\
\hline $3 \mathrm{~g} /$ pot & 65.77 & 68.33 & 75.66 & 79.88 & 72.41 & 24.17 & 28.18 & 31.16 & 35.18 & 29.67 \\
\hline $5 \mathrm{~g} /$ pot & 77.13 & 80.33 & 86.14 & 88.13 & 82.93 & 36.44 & 39.18 & 43.15 & 46.00 & 41.19 \\
\hline $7 \mathrm{~g} / \mathrm{pot}$ & 85.18 & 89.15 & $94 . .02$ & 98.55 & 91.72 & 42.90 & 46.12 & 50.66 & 55.16 & 48.71 \\
\hline Mean & 70.30 & 73.49 & 79.01 & 82.97 & & 31.21 & 34.17 & 37.04 & 40.37 & \\
\hline \multicolumn{11}{|l|}{ LSD at $5 \%$ for: } \\
\hline BA & & & 2.21 & & & & & 2.03 & & \\
\hline Fertilization & & & 2.21 & & & & & 2.03 & & \\
\hline BA $\times$ fertilization & & & 4.42 & & & & & 4.06 & & \\
\hline
\end{tabular}

the values of the tested vegetative growth measurements. This trend was true in both seasons. In general, the highest values of plant height, number of branches/plant, stem diameter, fresh and dry weights of shoots/plant (g) were recorded by fertilized Cupressus macrocarpa plants by kristalon fertilizer at $7 \mathrm{~g} /$ pot and sprayed with BA at $100 \mathrm{ppm}$ as compared with the other treatments as an average of both seasons, followed by the treatment consisting of the use of benzyladenine at $75 \mathrm{ppm}$ as foliar spray, combined with the addition of chemical fertilizers using kristalon fertilizer at a concentration of $7 \mathrm{~g} / \mathrm{pot}$ for all the characteristics studied in both seasons. On contrary, the lowest values were obtained in control plants.

The obtained results may be due to the role of benzyladenine, as it encourages the plant to increase its growth and development, so it increases some of the processes inside the plant, it helps to increase the division and development of plant cells and affects the cell walls, which facilitates the entry of water, nutrition and absorbs it in large quantities, thus increasing the growth of the plant as it helps in analyzing carbohydrates inside the plant (Runkle, 2006) and affect the development of chloroplasts development and has a role in the synthesis of chlorophyll and the preservation of it and prevent its demolition and thus a reflection on the general condition of the plant and the characteristics of growth and the presence of benzyl adenine prevents aging and maintains the freshness of the plant always (Majidian et al., 2012). Also, Cheema and Sharma (1982) they stated that these results may be explained according to the role of $\mathrm{BA}$ on promoting protein synthesis, increasing cell division and 
Table 3. Effect of benzyladenine (BA) and kristalon chemical fertilizer treatments on stem diameter $(\mathrm{cm})$ and fresh weights of shoots (g)/plant of Cupressus macrocarpa plants during 2017 and 2018 seasons.

\begin{tabular}{|c|c|c|c|c|c|c|c|c|c|c|}
\hline \multirow{3}{*}{ Fertilization treatments } & \multirow{2}{*}{\multicolumn{4}{|c|}{$\begin{array}{l}\text { Stem diameter }(\mathbf{c m}) \\
\text { BA }\end{array}$}} & \multirow{2}{*}{\multicolumn{6}{|c|}{$\begin{array}{l}\text { Fresh weight of shoots(g)/plant } \\
\text { BA }\end{array}$}} \\
\hline & & & & & & & & & & \\
\hline & 0.0 & $\begin{array}{c}50 \\
\text { ppm }\end{array}$ & $\begin{array}{c}75 \\
\text { ppm }\end{array}$ & $\begin{array}{c}100 \\
\text { ppm }\end{array}$ & Mean & 0.0 & $\begin{array}{c}25 \\
\text { ppm }\end{array}$ & $\begin{array}{c}75 \\
\text { ppm }\end{array}$ & $\begin{array}{c}100 \\
\text { ppm }\end{array}$ & Mean \\
\hline & \multicolumn{10}{|c|}{ First season: 2017} \\
\hline 0.0 & 0.97 & 1.01 & 1.11 & 1.19 & 1.07 & 915.96 & 930.60 & 931.92 & 939.96 & 929.61 \\
\hline 3 g/pot & 1.15 & 1.27 & 1.30 & 1.43 & 1.28 & 942.00 & 961.92 & 1021.56 & 1081.52 & 1001.70 \\
\hline $5 \mathrm{~g} / \mathrm{pot}$ & 1.35 & 1.55 & 1.65 & 1.70 & 1.56 & 1093.80 & 1155.96 & 1189.80 & 1201.20 & 1160.19 \\
\hline 7 g/pot & 1.48 & 1.80 & 2.12 & 2.41 & 1.95 & 1194.12 & 1261.20 & 1303.20 & 1380.00 & 1284.63 \\
\hline Mean & 1.24 & 1.40 & 1.54 & 1.68 & & 1036.47 & 1077.42 & 1111.62 & 1150.62 & \\
\hline \multicolumn{11}{|l|}{ LSD at $5 \%$ for: } \\
\hline BA & & & 0.14 & & & & & 32.4 & & \\
\hline Fertilization & & & 0.14 & & & & & 32.4 & & \\
\hline \multirow[t]{2}{*}{ BA $\times$ fertilization } & & & 0.28 & & & & & 64.8 & & \\
\hline & \multicolumn{10}{|c|}{ Second season: 2018} \\
\hline 0.0 & 1.12 & 1.18 & 1.23 & 1.31 & 1.21 & 959.88 & 1033.80 & 1056.12 & 1081.32 & 1032.78 \\
\hline 3 g/pot & 1.33 & 1.41 & 1.50 & 1.61 & 1.46 & 1105.44 & 1153.56 & 1201.80 & 1297.20 & 1189.50 \\
\hline 5 g/pot & 1.49 & 1.59 & 1.79 & 1.88 & 1.69 & 1310.40 & 1371.60 & 1441.32 & 1479.96 & 1400.82 \\
\hline 7 g/pot & 1.69 & 1.96 & 2.22 & 2.50 & 2.07 & 1507.20 & 1602.00 & 1706.40 & 1798.80 & 1653.60 \\
\hline Mean & 1.40 & 1.53 & 1.68 & 1.82 & & 1220.73 & 1290.24 & 1351.41 & 1414.32 & \\
\hline \multicolumn{11}{|l|}{ LSD at $5 \%$ for: } \\
\hline $\mathbf{B A}$ & & & 0.12 & & & & & 41.2 & & \\
\hline Fertilization & & & 0.12 & & & & & 41.2 & & \\
\hline BA $\times$ fertilization & & & 0.24 & & & & & 82.4 & & \\
\hline
\end{tabular}

Table 4. Effect of benzyladenine (BA) and kristalon chemical fertilizer treatments on dry weight of shoots (g)/plant of Cupressus macrocarpa plants during 2017 and 2018 seasons.

\begin{tabular}{|c|c|c|c|c|c|c|c|c|c|c|}
\hline \multirow{4}{*}{ Fertilization treatments } & \multicolumn{10}{|c|}{ Dry weight of shoots (g)/plant } \\
\hline & \multirow{2}{*}{\multicolumn{4}{|c|}{$\begin{array}{l}\text { First season: } 2017 \\
\text { BA }\end{array}$}} & \multirow{2}{*}{\multicolumn{6}{|c|}{$\begin{array}{l}\text { Second season: } 2018 \\
\text { BA }\end{array}$}} \\
\hline & & & & & & & & & & \\
\hline & 0.0 & $\begin{array}{c}50 \\
\text { ppm }\end{array}$ & $\begin{array}{c}75 \\
\text { ppm }\end{array}$ & $\begin{array}{l}100 \\
\text { ppm }\end{array}$ & Mean & 0.0 & $\begin{array}{c}25 \\
\text { ppm }\end{array}$ & $\begin{array}{c}75 \\
\text { ppm }\end{array}$ & $\begin{array}{l}100 \\
\text { ppm }\end{array}$ & Mean \\
\hline$\overline{0.0}$ & 332.40 & 337.80 & 338.28 & 341.16 & 337.41 & 337.56 & 363.84 & 371.64 & 380.52 & 363.39 \\
\hline $3 \mathrm{~g} / \mathrm{pot}$ & 341.88 & 348.00 & 370.80 & 392.40 & 363.27 & 389.16 & 406.08 & 422.76 & 456.60 & 418.65 \\
\hline $5 \mathrm{~g} / \mathrm{pot}$ & 396.96 & 418.80 & 431.88 & 436.08 & 420.93 & 384.96 & 482.76 & 507.24 & 520.80 & 473.94 \\
\hline 7 g/pot & 433.44 & 457.80 & 472.80 & 500.88 & 466.23 & 420.24 & 563.76 & 600.36 & 633.24 & 554.40 \\
\hline Mean & 376.17 & 390.60 & 403.44 & 417.63 & & 382.98 & 454.11 & 475.50 & 497.79 & \\
\hline \multicolumn{11}{|l|}{ LSD at $5 \%$ for: } \\
\hline BA & & & 14.5 & & & & & 36.3 & & \\
\hline Fertilization & & & 14.5 & & & & & 36.3 & & \\
\hline BA $\times$ fertilization & & & 29.0 & & & & & 72.6 & & \\
\hline
\end{tabular}


enlargement. Furthermore, on improvement soluble and non-soluble sugars synthesis or may be due to the ability of benzyladenine for making the treated area to act as a sink in which nutrients from other parts of the plant are drawn (Salisbury and Ross, 1974). It is known that the use of growth regulators in agriculture practices is of great importance and role in improving the growth of different plants, whether vegetative growth, or growth in general (Sajjad et al., 2017), cytokinins are plant hormones that regulate many processes inside the plant and have a clear effect on plant growth and development. This comes from its role in cell division, differentiation, and leaf extension, which in turn is reflected in increasing plant growth and development (Hassan and El-Quesni, 1989 and Shudok, 1994). Also, Sorour and El-Shanhorey (2016) stated that treating Dracaena marginata plant by using BA at $300 \mathrm{mg} / \mathrm{l}$ and $\mathrm{GA}_{3}$ at $1000 \mathrm{mg} / \mathrm{l}$ encouraged the maximum values of plant height, stem diameter, number of branches/plant. The aforementioned results of benzyladenine are in conformity with those reported by El-Malt et al. (2006) on Hippeastrum vittatum, Chopde et al. (2015) on gladiolus, Youssef and Mady (2013) on Aspidistra elatior and Ibrahim et al. (2010) and Eid and AbouLeila (2006) on croton plant, and Salehi Sardoei (2014) on Aloe barbadensis.

The above-mentioned results regarding chemical fertilization indicate the important role of nitrogen, phosphorous and potassium within the plant, especially the role of these elements in the important and different physiological processes in the plant, which in turn are reflected in the processes of growth and development within the plant. The nitrogen is necessary for the formation of amino acids and nucleic acids and thus the composition of the important protein of the plant, it is also necessary for many enzymes and energy transfer compounds ADP and ATP in plant tissue (Taiz and Zeiger, 2002). The phosphorous is important for influencing many processes within the plant such as cell division and growth, energy transfer (ATP and ADP), photosynthesis and respiration (Raghothama, 1999). As for, potassium is necessary in the formation and transportation of sugar and starch, protein synthesis, cell division and help in the absorption and movement of other nutrients within the plant. From the above, it becomes clear the importance of chemical fertilization and its great role in many different processes within the plant, which in turn is reflected in the increase the vegetative growth of plants. Hence, increasing the quality and productivity of plants. (Stiles, 2006 and Reza et al., 2017).

The abovementioned results of fertilization are in harmony with those attained by Singh et al. (2002) on Gladiolus grandiflorum, Pal and Biswas (2005) on Polianthes tuberosa L., El-Malt et al. (2006) on Hippeastrum vittatum, Abou Dahab et al. (2017) on Chamaedorea elegans, Abou-ElElla (2007) on Acanthus mollis, El-Naggar and El-Nasharty (2009) on Hippeastrum vittatum, Ghatas (2020) on coriander plants, Wanderley et al. (2012) on areca bamboo palm, Youssef and Abd El-Aal (2014) on Hippeastrum vittatum, Hussein (2009) on Cryptostegia grandifloraand. Kashif et al. (2014) demonstrated that using chemical fertilizer improved vegetative growth parameters on Dahlia hybrida. In the same time, Abbasniayzare et al. (2012) indicated that treating Spathiphyllum illusion by NPK fertilizer treatments gave the best results for leaves number, dry and fresh weights of leaves per plant. In addition, Youssef (2014) declared that fertilizing Beaucarnea recurvata with kristalon fertilizer at $6 \mathrm{~g}$ /pot is necessary for improving the growth, quality and nutritional status of the plants. On another paper, Ghatas (2015) showed that using the combined treatment between NPK chemical fertilizer and kinetine at 75 ppm enhanced the growth and quality on Hemerocallis aurantiaca. Also, Hamad (2020) demonstrated that spraying Aspidistra elatior plant with kristalon fertilizer at $6 \mathrm{~g} / \mathrm{l}$ gave the best vegetative growth parameters. In this context, Mostafa (2018) showed that growing areca palm plants in a medium containing composted + peat moss + 
vermiculite or a medium composed of clay + peat moss 1:1:1 (v:v:v) and sprayed with chemical fertilizer at $6 \mathrm{~g} / \mathrm{l}$ produced the best plant height, stem diameter, stem length number of leaves/plant and fresh, dry weights of leaves (g) of this plant.

\section{Root growth measurements:}

Data in Table (5) illustrated that spraying treatments with different concentrations of benzyladenine treatments statistically improved fresh and dry weights of roots/plant, especially the high concentrations at $100 \mathrm{ppm}$ and $75 \mathrm{ppm}$ in both seasons, respectively. On the other hand, the kristalon chemical fertilization treatments were more effective in increasing the values of fresh and dry weights of roots/plant for Cupressus macrocarpa as compared with control (tap water) plants, which no receiving fertilization in both seasons. Therefore, the use of chemical fertilizers with kristalon as chemical fertilization at a concentration of $7 \mathrm{~g} / \mathrm{pot}$ resulted in obtaining the highest and best results of these parameters for Cupressus macrocarpa plants when compared to control plants with no fertilizer during the two seasons. With regard to the interaction effect between BA concentrations and kristalon chemical fertilization, it is obvious from Table (5) that the lemon cypress plant which fertilized with kristalon chemical fertilizer at $7 \mathrm{~g} /$ pot and sprayed by using 100 ppm of BA significantly increased all parameters of roots under study. Also, the treatment came with the use of benzyladenine at $75 \mathrm{ppm}$ with krystalon as a chemical fertilizer with a concentration of 7 $\mathrm{g} / \mathrm{pot}$, in second place in the same context in the first and second seasons. On contrary, the lowest values were obtained when kristalon

Table 5. Effect of benzyladenine (BA) and kristalon chemical fertilizer treatments on fresh and dry weights of roots (g)/plant of Cupressus macrocarpa plants during 2017 and 2018 seasons.

\begin{tabular}{|c|c|c|c|c|c|c|c|c|c|c|}
\hline \multirow{3}{*}{ Fertilization treatments } & \multirow{2}{*}{\multicolumn{5}{|c|}{$\begin{array}{l}\text { Fresh weight of roots (g)/plant } \\
\text { BA }\end{array}$}} & \multirow{2}{*}{\multicolumn{5}{|c|}{$\begin{array}{l}\text { Dry weight of roots }(g) / \text { plant } \\
\text { BA }\end{array}$}} \\
\hline & & & & & & & & & & \\
\hline & 0.0 & $\begin{array}{c}50 \\
\text { ppm }\end{array}$ & $\begin{array}{c}75 \\
\text { ppm }\end{array}$ & $\begin{array}{c}100 \\
\text { ppm }\end{array}$ & Mean & 0.0 & $\begin{array}{c}25 \\
\text { ppm }\end{array}$ & $\begin{array}{c}75 \\
\text { ppm }\end{array}$ & $\begin{array}{l}100 \\
\text { ppm }\end{array}$ & Mean \\
\hline & \multicolumn{10}{|c|}{ First season: 2017} \\
\hline 0.0 & 34.66 & 36.22 & 36.15 & 39.18 & 36.55 & 4.46 & 4.64 & 4.62 & 5.01 & 4.68 \\
\hline $3 \mathrm{~g} /$ pot & 37.01 & 40.19 & 40.88 & 42.18 & 40.06 & 4.74 & 5.14 & 5.23 & 5.40 & 5.12 \\
\hline $5 \mathrm{~g} / \mathrm{pot}$ & 41.19 & 45.17 & 49.13 & 50.33 & 46.45 & 5.27 & 5.78 & 6.30 & 6.70 & 6.01 \\
\hline $7 \mathrm{~g} /$ pot & 48.22 & 50.11 & 55.02 & 61.73 & 53.77 & 6.17 & 6.55 & 7.04 & 7.91 & 6.91 \\
\hline Mean & 40.27 & 42.92 & 45.29 & 48.35 & & 5.16 & 5.52 & 5.79 & 6.25 & \\
\hline \multicolumn{11}{|l|}{ LSD at $5 \%$ for: } \\
\hline BA & & & 2.14 & & & & & 0.21 & & \\
\hline Fertilization & & & 2.14 & & & & & 0.21 & & \\
\hline \multirow[t]{2}{*}{ BA $\times$ fertilization } & & & 4.28 & & & & & 0.42 & & \\
\hline & \multicolumn{10}{|c|}{ Second season: 2018} \\
\hline 0.0 & 33.18 & 35.18 & 38.44 & 40.33 & 36.78 & 4.15 & 4.40 & 4.81 & 5.04 & 4.60 \\
\hline $3 \mathrm{~g} / \mathrm{pot}$ & 39.44 & 42.33 & 46.15 & 49.99 & 44.47 & 4.90 & 5.29 & 5.78 & 6.26 & 5.55 \\
\hline $5 \mathrm{~g} / \mathrm{pot}$ & 47.33 & 50.00 & 50.99 & 55.88 & 51.05 & 5.89 & 6.26 & 6.37 & 7.02 & 6.38 \\
\hline 7 g/pot & 51.22 & 55.12 & 58.09 & 63.92 & 57.08 & 6.34 & 6.91 & 7.26 & 8.01 & 7.13 \\
\hline Mean & 42.79 & 45.65 & 48.41 & 52.53 & & 5.32 & 5.71 & 6.05 & 6.58 & \\
\hline \multicolumn{11}{|l|}{ LSD at $5 \%$ for: } \\
\hline BA & & & 2.40 & & & & & 0.31 & & \\
\hline Fertilization & & & 2.40 & & & & & 0.31 & & \\
\hline BA $\times$ fertilization & & & 4.80 & & & & & 0.62 & & \\
\hline
\end{tabular}


fertilizer was not added to plants and was not sprayed with benzyl adenine in both seasons.

These results might be interpreted according to the role of benzyladenine on promoting proteins synthesis, soluble and non-soluble sugars synthesis, or may be due to the ability of benzyladenine for making the treated area to act as a sink into which nutrients from other parts of the plant are drawn. Additionally, these results may explain the role of cytokinins in promoting proteins and pigments synthesis and their ability to delay senescence and withdraw sugars and other solutes from older parts of a plant to the new organs (Sajjad et al., 2017). In the same line, may be due to the role of benzyladenine on increasing the promoters in the plant tissues at the expense of the inhibitors to increase roots growth. Moreover, it is well established that cytokinins stimulate lateral roots initiation and thus increasing the size (number, thickness, fresh and dry weights (Devlin and Witham, 1983).

The abovementioned results of benzyladenine are in harmony with those achieved by Matin et al. (2015) on Narcissus tazetta, Manasa et al. (2017) on gladiolus plant, Maximoos (1993) on Gerbera jamesonii, Sorour and El-Shanhorey (2016) stated that spraying Dracaena marginata with $\mathrm{BA}$ at $300 \mathrm{mg} / \mathrm{l}+1000 \mathrm{mg} / \mathrm{l}$ of $\mathrm{GA}_{3}$ together increased significantly root length and root dry weight. Also, Youssef and Mady (2013) stated that treating Aspidistra elatior plants with benzyladenine at $75 \mathrm{ppm}$ gave the best root growth parameters.

The obtained results of chemical fertilization are in harmony with those attained by El-Aziz (2007) on Codiaeum variegatum, Ghatas (2015) on Hemerocallis aurantiaca, Abou El-Ella (2007) on Acanthus mollis, El-Naggar and El- Nasharty (2009) on Hippeastrum vittatum, Hussein (2009) on Cryptostegia grandiflora, Habib (2012) on Caryota mitis Lour, Hamad (2020) on Aspidistra elatior, El-Sayed and Ismail (2017) on Codiaeum variegatum, Wanderley et al. (2012) on areca bamboo palm (Dypsis lutescens), Youssef and Abd El-Aal (2014) on Hippeastrum vittatum. Youssef (2014) found that fertilizing of Beaucarnea recurvata with kristalon fertilizer at $6 \mathrm{~g} / \mathrm{pot}$ is necessary for improving the growth, quality and nutritional status of the plants. Mazhar and Eid (2016) showed that kristalon at $80 \mathrm{mg} / \mathrm{m}^{2}+80 \mathrm{ml} / \mathrm{m}^{2}$ gave the maximum values of all growth parameters of Gladiolus grandiflorus in both seasons compared with untreated plants. Also, Mostafa (2018) illustrated that growing Dypsis cabadae H.E. Moore on medium contained compost + peat moss + vermiculite or clay + peat moss and fertilized with kristalon at $6 \mathrm{~g} / \mathrm{l}$ produced the best root growth parameters.

\section{Chemical composition:}

Data in Tables (6-8) indicated that all applied treatments of benzyladenine and kristalon fertilizer as well as their interactions showed a pronounced positive effect on increasing leaf $\mathrm{N}, \mathrm{P}$ and $\mathrm{K} \%$, total carbohydrates \%, total chlorophylls and carotenoids content of Cupressus macrocarpa plants in both seasons. The increments of leaf chemical composition contents were in parallel to the increasing of benzyladenine treatment levels, to reach the maximum increasing at the high level in both seasons as compared with untreated plant control (tap water). On the other hand, all tested concentrations of kristalon chemical fertilizer increased leaf $\mathrm{N}, \mathrm{P}$ and $\mathrm{K} \%$, and photosynthetic pigments content as compared with control plants in both seasons. Hence, the high concentration of chemical fertilization gave the best values for leaf $\mathrm{N}, \mathrm{P}, \mathrm{K} \%$ and photosynthetic pigments in the first and second season. In general, all the interaction effects between benzyladenine and kristalon fertilizer treatments statistically increased the values of these parameters as compared with control in both seasons. However, the highest values of leaf total carbohydrates (\%), leaf total chlorophylls (mg/100 g F.W) and carotenoids (mg/g F.W) content were recorded by using kristalon chemical fertilizer at $7 \mathrm{~g} / \mathrm{pot}+100 \mathrm{ppm}$ of BA, 
Table 6. Effect of benzyladenine (BA) and kristalon chemical fertilizer treatments on $\mathbf{N}$ and $P \%$ of Cupressus macrocarpa plants during 2017 and 2018 seasons.

\begin{tabular}{|c|c|c|c|c|c|c|c|c|c|c|}
\hline \multirow{3}{*}{ Fertilization treatments } & \multicolumn{4}{|c|}{$\mathrm{N} \%$} & \multicolumn{6}{|c|}{ P \% } \\
\hline & \multicolumn{4}{|c|}{ BA } & \multicolumn{6}{|c|}{ BA } \\
\hline & 0.0 & $\begin{array}{c}50 \\
\text { ppm }\end{array}$ & $\begin{array}{c}75 \\
\text { ppm } \\
\end{array}$ & $\begin{array}{c}100 \\
\text { ppm }\end{array}$ & Mean & 0.0 & $\begin{array}{c}25 \\
\text { ppm }\end{array}$ & $\begin{array}{c}75 \\
\text { ppm }\end{array}$ & $\begin{array}{c}100 \\
\text { ppm }\end{array}$ & Mean \\
\hline & \multicolumn{10}{|c|}{ First season: 2017} \\
\hline 0.0 & 2.15 & 2.16 & 2.18 & 2.26 & 2.18 & 0.187 & 0.190 & 0.210 & 0.225 & 0.203 \\
\hline $3 \mathrm{~g} / \mathrm{pot}$ & 2.22 & $2 . .24$ & 2.35 & 2.48 & 2.32 & 0.191 & 0.224 & 0.253 & 0.265 & 0.233 \\
\hline $5 \mathrm{~g} / \mathrm{pot}$ & 2.33 & 2.50 & 2.66 & 2.79 & 2.57 & 0.258 & 0.268 & 0.281 & 0.292 & 0.274 \\
\hline 7 g/pot & 2.56 & 2.84 & 3.23 & 3.64 & 3.06 & 0.289 & 0.301 & 0.321 & 0.350 & 0.315 \\
\hline Mean & 2.31 & 2.43 & 2.60 & 2.79 & & 0.231 & 0.245 & 0.266 & 0.283 & \\
\hline \multicolumn{11}{|l|}{ LSD at $5 \%$ for: } \\
\hline BA & & & 0.19 & & & & & 0.013 & & \\
\hline Fertilization & & & 0.19 & & & & & 0.013 & & \\
\hline \multirow[t]{2}{*}{ BA $\times$ fertilization } & & & 0.38 & & & & & 0.026 & & \\
\hline & \multicolumn{10}{|c|}{ Second season: 2018} \\
\hline 0.0 & 2.203 & 2.25 & 2.24 & 2.34 & 2.25 & 0.210 & 0.218 & 0.220 & 0.223 & 0.217 \\
\hline $3 \mathrm{~g} / \mathrm{pot}$ & 2.36 & 2.40 & 2.56 & 2.67 & 2.49 & 0.225 & 0.239 & 0.241 & 0.251 & 0.239 \\
\hline $5 \mathrm{~g} / \mathrm{pot}$ & 2.49 & 2.73 & 2.84 & 2.95 & 2.75 & 0.250 & 0.259 & 0.260 & 0.273 & 0.260 \\
\hline $7 \mathrm{~g} /$ pot & 2. 60 & 3.01 & 3.44 & 3.81 & 3.21 & 0.265 & 0.292 & 0.329 & 0.360 & 0.311 \\
\hline Mean & 2.41 & 2.59 & 2.76 & 2.94 & & 0.237 & 0.252 & 0.262 & 0.276 & \\
\hline \multicolumn{11}{|l|}{ LSD at $5 \%$ for: } \\
\hline BA & & & 0.17 & & & & & 0.014 & & \\
\hline Fertilization & & & 0.17 & & & & & 0.014 & & \\
\hline BA $\times$ fertilization & & & 0.34 & & & & & 0.028 & & \\
\hline
\end{tabular}

sprayed on Cupressus macrocarpa plants in the first and second seasons, respectively. On contrary, the lowest values were obtained when kristalon fertilizer was not added to plants and was not sprayed with benzyladenine in both seasons. From the previous results, it is clear that the different concentrations of the treatments under study conducted on the lemon cypress plant, either separately or mixed among them, gave the best results in the chemical composition of cypress plants compared to control plants in both seasons. Knowing that the best of these results were achieved by using the high concentration of benzyladenine at $100 \mathrm{ppm}$ combined with kristalon chemical fertilization at $7 \mathrm{~g} / \mathrm{pot}$, compared to the control plants in both seasons. It was followed in the same context by the treatment consisting of benzyladenine at 75 ppm $+7 \mathrm{~g}$ /pot of chemical fertilization as it achieved the second best results for the chemical contents in both seasons compared to the control plants.

The abovementioned results of the incremental effect of BA on chemical constituents of Cupressus macrocarpa, this can be illustrated by the fact that benzyladenine stimulates the synthesis and activation of the action of internal cytokinins, which in turn is reflected on plant growth, as there is an intimate relationship between cytokinins and metabolism of chlorophyll in both excided or detached leaf disks and intact plants i.e. cytokinins retard chlorophylls degradation, preserve it and increase its synthesis. (Devlin and Witham, 1983). Besides, cytokinins activate the action of many enzymes involved in many metabolic reactions in leaves. This includes increasing maturity in green chloroplasts. These enzymes can be divided into two 
Table 7. Effect of benzyladenine (BA) and kristalon chemical fertilizer treatments on $\mathrm{K}$ $\%$ and of total carbohydrates (\%) of Cupressus macrocarpa plants during 2017 and 2018 seasons.

\begin{tabular}{|c|c|c|c|c|c|c|c|c|c|c|}
\hline \multirow{3}{*}{ Fertilization treatments } & \multicolumn{5}{|c|}{ K \% } & \multicolumn{5}{|c|}{ Total carbohydrates (\%) } \\
\hline & \multicolumn{4}{|c|}{ BA } & \multicolumn{6}{|c|}{ BA } \\
\hline & 0.0 & $\begin{array}{c}50 \\
\text { ppm }\end{array}$ & $\begin{array}{c}75 \\
\text { ppm }\end{array}$ & $\begin{array}{c}100 \\
\text { ppm }\end{array}$ & Mean & 0.0 & $\begin{array}{c}25 \\
\text { ppm }\end{array}$ & $\begin{array}{c}75 \\
\text { ppm }\end{array}$ & $\begin{array}{c}100 \\
\text { ppm }\end{array}$ & Mean \\
\hline & \multicolumn{10}{|c|}{ First season: 2017} \\
\hline 0.0 & 1.29 & 1.30 & 1.33 & 1.35 & 1.31 & 9.93 & 10.22 & 10.33 & 10.66 & 10.28 \\
\hline 3 g/pot & 1.38 & 1.42 & 1.48 & 1.52 & 1.45 & 10.44 & 11.13 & 11.55 & 12.09 & 11.3 \\
\hline $5 \mathrm{~g} /$ pot & 1.59 & 1.65 & 1.69 & 1.72 & 1.66 & 12.00 & 12.88 & 13.12 & 14.66 & 13.16 \\
\hline 7 g/pot & 1.63 & 1.85 & 1.90 & 2.39 & 1.94 & 13.88 & 15.66 & 16.33 & 19.02 & 16.22 \\
\hline Mean & 1.47 & 1.55 & 1.60 & 1.74 & & 11.56 & 12.47 & 12.83 & 14.10 & \\
\hline \multicolumn{11}{|l|}{ LSD at $5 \%$ for: } \\
\hline BA & & & 0.11 & & & & & 0.91 & & \\
\hline Fertilization & & & 0.11 & & & & & 0.91 & & \\
\hline BA $\times$ fertilization & & & 0.22 & & & & & 1.82 & & \\
\hline & \multicolumn{10}{|c|}{ Second season: 2018} \\
\hline 0.0 & 1.26 & 1.31 & 1.38 & 1.47 & 1.35 & 10.01 & 10.44 & 11.11 & 11.66 & 10.80 \\
\hline $3 \mathrm{~g} /$ pot & 1.48 & 1.56 & 1.69 & 1.72 & 1.61 & 12.33 & 12.88 & 13.04 & 13.77 & 13.00 \\
\hline $5 \mathrm{~g} / \mathrm{pot}$ & 1.70 & 1.75 & 1.80 & 1.88 & 1.78 & 13.76 & 14.88 & 15.33 & 15.60 & 14.89 \\
\hline $7 \mathrm{~g} /$ pot & 1.81 & 1.90 & 2.20 & 2.56 & 2.12 & 15.23 & 15.66 & 16.44 & 19.66 & 16.75 \\
\hline Mean & 1.56 & 1.63 & 1.76 & 1.91 & & 12.83 & 13.46 & 13.98 & 15.17 & \\
\hline \multicolumn{11}{|l|}{ LSD at $5 \%$ for: } \\
\hline BA & & & 0.15 & & & & & 0.83 & & \\
\hline Fertilization & & & 0.15 & & & & & 0.83 & & \\
\hline BA $\times$ fertilization & & & 0.30 & & & & & 1.66 & & \\
\hline
\end{tabular}

groups according to their responses to cytokinins, where it can be said that the first group of enzymes relates to the characteristic of chloroplasts differentiation, while the second group is linked to cytokinin stimulated group (Taiz and Zeiger, 2010 and Kulaeva,1979). These results may also explain the role of cytokinins in protein and pigment synthesis and its ability to delay senescence and withdraw sugars and other solutes from older parts of a plant to the new organs (Taiz and Zeiger, 2002). In the same line Leopol and Kawase (1964) stated that cytokinins have a great role in stimulating many other solutes and increasing the movement of sugars, starches and amino acids from the mature organs to the primary tissues of other ones. Furthermore, this may be due to the role of benzyl adenine in improving and stimulating plant growth at the expense of growth inhibitors. In this regard, Kenneth (1979) mentioned that controlling growth within the plant is not only dependent on one type of hormone, but is shared by many hormones, especially auxins, cytokinins, gibberellins and ethylene in particular, in addition to the phenols, and abscisic acid, where it was mentioned that stimulants of growth in various stages within the plant at the expense of growth inhibitors.

The aforementioned results of benzyladenine are in conformity with those obtained by Matin et al. (2015) on Narcissus tazetta, Nambiar et al. (2012) on Dendrobium orchid. Also, Ali and Asil (2015) revealed that spraying Schefflera arboricola plants with cytokinins (BA) at $100 \mathrm{mg} / \mathrm{l}$ significantly increased photosynthetic pigments contents. Also Youssef and Mady (2013) stated that treating Aspidistra elatior by $75 \mathrm{ppm}$ of BA encouraged the best leaf $\mathrm{N}, \mathrm{P}, \mathrm{K}$ and 
Table 8. Effect of benzyladenine (BA) and kristalon chemical fertilizer treatments on total chlorophylls (mg/100 g F.W.) and carotenoids (mg/g F.W.) of Cupressus macrocarpa plants during 2017 and 2018 seasons.

\begin{tabular}{|c|c|c|c|c|c|c|c|c|c|c|}
\hline \multirow{3}{*}{ Fertilization treatments } & \multirow{2}{*}{\multicolumn{5}{|c|}{$\begin{array}{l}\text { Total chlorophylls (mg/100 g F.W.) } \\
\text { BA }\end{array}$}} & \multirow{2}{*}{\multicolumn{5}{|c|}{$\begin{array}{l}\text { Carotenoids (mg/g F.W.) } \\
\text { BA }\end{array}$}} \\
\hline & & & & & & & & & & \\
\hline & 0.0 & $\begin{array}{c}50 \\
\text { ppm }\end{array}$ & $\begin{array}{c}75 \\
\text { ppm } \\
\end{array}$ & $\begin{array}{c}100 \\
\text { ppm }\end{array}$ & Mean & 0.0 & $\begin{array}{c}25 \\
\text { ppm }\end{array}$ & $\begin{array}{c}75 \\
\text { ppm }\end{array}$ & $\begin{array}{l}100 \\
\text { ppm }\end{array}$ & Mean \\
\hline & \multicolumn{10}{|c|}{ First season: 2017} \\
\hline 0.0 & 214.1 & 215.3 & 215.8 & 216.8 & 215.5 & 0.112 & 0.125 & 0.133 & 0.146 & 0.129 \\
\hline 3 g/pot & 218.3 & 220.5 & 222.3 & 225.9 & 221.75 & 0.155 & 0.188 & 0.191 & 0.211 & 0.186 \\
\hline $5 \mathrm{~g} /$ pot & $226 . .9$ & 227.1 & 228.6 & 229.4 & 228.00 & 0.203 & 0.218 & 0.221 & 0.236 & 0.219 \\
\hline 7 g/pot & 227.5 & 230.7 & 240.1 & 253.9 & 238.05 & 0.225 & 0.235 & 0.263 & 0.318 & 0.260 \\
\hline Mean & 221.7 & 223.4 & 226.7 & 231.5 & & 0.173 & 0.191 & 0.202 & 0.228 & \\
\hline \multicolumn{11}{|l|}{ LSD at $5 \%$ for: } \\
\hline BA & & & 4.14 & & & & & 0.014 & & \\
\hline Fertilization & & & 4.14 & & & & & 0.014 & & \\
\hline \multirow[t]{2}{*}{ BA $\times$ fertilization } & & & 8.28 & & & & & 0.028 & & \\
\hline & \multicolumn{10}{|c|}{ Second season: 2018} \\
\hline 0.0 & 215.6 & 216.7 & 218.3 & 219.9 & 217.62 & 0.113 & 0.126 & 0.141 & 0.162 & 0.135 \\
\hline $3 \mathrm{~g} / \mathrm{pot}$ & 220.4 & 225.3 & 226.6 & 229.1 & 225.35 & 0.171 & 0.179 & 0.183 & 0.192 & 0.181 \\
\hline $5 \mathrm{~g} /$ pot & 231.3 & 236.2 & 238.4 & 246.8 & 238.17 & 0.215 & 0.268 & 0.273 & 0.280 & 0.259 \\
\hline 7 g/pot & 234.2 & 246.4 & 251.7 & 265.9 & 249.55 & 0.296 & 0.335 & 0.355 & 0.389 & 0.344 \\
\hline Mean & 225.32 & 231.15 & 233.75 & 240.42 & & 0.198 & 0.227 & 0.238 & 0.256 & \\
\hline \multicolumn{11}{|l|}{ LSD at $5 \%$ for: } \\
\hline BA & & & 6.37 & & & & & 0.013 & & \\
\hline Fertilization & & & 6.37 & & & & & 0.013 & & \\
\hline BA $\times$ fertilization & & & 12.70 & & & & & 0.026 & & \\
\hline
\end{tabular}

photosynthetic pigments contents.On another paper,, Sorour and El-Shanhorey (2016) stated that spraying Dracaena marginata with BA at $250 \mathrm{mg} / \mathrm{l}+1000 \mathrm{mg} / \mathrm{l}$ of $\mathrm{GA}_{3}$ together encouraged the highest chlorophyll content, carbohydrates content and nitrogen percentage in the leaves. In the same context, Ramtin et al. (2016) pointed out that the use of foliar spray with a concentration $150 \mu \mathrm{M}$ of benzyladenine led to an apparent effect and increase in the plant content of chlorophyll (a) and (b) on carnation plants.

The aforementioned results of fertilization are in harmony with those attained by Younis et al. (2004) on Jasminum grandiflorum, El-Naggar and ElNasharty (2009) on Hippeastrum vittatum, Abd El-All (2011) on Aspidistra elatior, Ghatas and Abdallah (2016) on Echinacea purpurea, Rodrigo et al. (2011) on Pinus nigra and Betula papyrifera, Habib(2012) on
Caryota mitis Lour, Ghatas (2020) on coriander, Wanderley et al. (2012) on areca bamboo palm (Dypsis lutescens), Youssef and Abd El-Aal (2014) on Hippeastrum vittatum, Youssef (2014) on Beaucarnea recurvata and Mazhar and Eid (2016) on Gladiolus grandiflorus, Ghatas (2016) stated that adding NPK chemical fertilizer at 4 or 6 g/plant on Gladiolus grandiflorus significantly increased leaf N, P, K and total carbohydrates content. Also, Mohamed (2018) demonstrated that using kristalon fertilizer at $8 \mathrm{~g} /$ pot produced the best values of leaves contents of $\mathrm{N}, \mathrm{P}, \mathrm{K} \%$ and photosynthetic pigments of Dypsis cabadae.

\section{CONCLUSION}

The present results reported about the vegetative growth, root growth parameters and chemical compositions of Cupressus macrocarpa L., demonstrated that the best 
spraying treatments of benzyladenine when using the maximum concentration combined with the highest level of kristalon fertilizer that gave the best quality results for all the studied parameters of lemon cypress plants. Generally, it is pereferable to spray lemon cypress (Cupressus macrocarpa L.) plants with benzyladenine at $100 \mathrm{ppm}$ combined with $7 \mathrm{~g} /$ pot of kristalon chemical fertilizer to maximize the growth and quality of lemon cypress plants.

\section{REFERENCES}

Abbasniayzare, S.K.; Sedaghathoor, S. and Dahkaei, M.N.P. (2012). Effect of Biofertilizer Application on Growth Parameters of Spathiphyllum illusion. J. Agric. and Environ. Sci. 12(5):669-673.

Abd Al Lateef, S. and Hade, S. (2018). The effect of foliar applications with gibberellic acid and benzyladenin on vegetative and floral growth of pansy plant (Viola Tricolor). Journal of Agriculture and Veterinary Science, 11(3):12-17.

Abd El-All, S.G. (2011). Response of Castiron Plant (Aspidistra elatior Blume) to Foliar Nutrition With Greenzit and GA3. M.Sc. Thesis, Fac. Agric., Benha Univ., Egypt, 129 p.

Abou Dahab, T.A.M.; Ashour, H.A.; ElDeeb, E.E.A. and Saber, M.M.H. (2017). Response of Chamaedorea elegans, Mart. plants grown under different light intensity levels to chemical and organic fertilization treatments. Journal of Horticultural Science \& Ornamental Plants 9(2):72- 85.

Abou El-Ella, E.M. (2007). Physiological Studies on Acanthus mollis Plant. M.Sc. Thesis, Fac. Agric., Benha Univ., Egypt, $80 \mathrm{p}$.

Ali, S.S. and Asil, M. H. (2015). Response of application of gibberlic acid and benzyladenine to Shefflera arboricola L. plants. Journal of Dama International, 3(2):290-297.
Ali, S.S.; Zarinkolah, M. and Alavi, S.M.H. (2018). Response of false aralia plant to gibberellic acid and benzyladenine application. International Journal of Advanced Biological and Biomedical Research, 7(1):47-52.

A.O.A.C. (1990). Official Methods of Analysis (15 $5^{\text {th }}$ ed.). Association of Official Analytical Chemists, Washington D.C., USA. 1298 p.

Black, C.D.; Evans, D.O.; Ensminger, L.E.; White, J.L.; Clark, F.E. and Dinauer, R.C. (1982). Methods of soil analysis Part 2, Chemical and Microbiological Properties, $2^{\text {nd }}$ ed. Soil. Soc. of Am. Inc. Publ., Madison, Wisconsin, U.S.A., $1159 \mathrm{p}$.

Cheema, G.S. and Sharma, D.P. ( 1982). In vitro propagation of apple rootstocks. Int. Hort. Congr XXI. Hamburg, German Federal Republic, Int. Soc. Hort. Sci. Vol. 1: 1035 (Chem. Abst., 52: 7692).

Chopde, N.; Patil, A. and Bhande, M.H. (2015). Growth, yield and quality of gladiolus as influenced by growth regulators and methods of application. Plant Arch., 15(2):691-694.

Devlin, M. and Witham, H. (1983). Plant Physiology, $4^{\text {th }}$ ed. Publishers Willard, Grant Press, Boston, 577 p.

Eid, R.A. and Abou-Leila, B.H. (2006). Response of croton plants to gibberellic acid, benzyladenine and ascorbic acid application. World J. Agric. Sci., 2(2):174-179.

El-Aziz, N.G.A. (2007). Stimulatory effect of NPK fertilizer and benzyladenine on growth and chemical constituent of Codiaeum variegatum L. plant. American Eurasian J. of Agric. and Environ. Sci., Deira, 2:711-719.

El-Malt, A.A.T.; El-Maadawy, E.E; ElKhateeb, M.A. and El-Sadak, Z.H. (2006). Physiological studies on Hippeastrum vittatum L. plants, II- Effect of NPK, CCC and BA on growth, bulblet 


\section{Y.A.A. Ghatas}

production and flowering. Egypt. J. of Appl. Sci., 6B:724-74 2.

El-Naggar, A.H. and El-Nasharty, A.B. (2009). Effect of growing media and mineral fertilization on growth, flowering, bulbs productivity and chemical constituents of Hippeastrum vittatum, Herb. American-Eurasian J. Agric. and Environ. Sci., 6(3):360-371.

El-Naggar, A.H.; Esmaiel, N.M. and ElNaggar, A.A. (2016). Effect of mineral and bio- fertilization on vegetative growth and flowering of Anthurium andreanum L. plants under greenhouse conditions. Alexandria Science Exchange Journal, 37(1):1-9.

El-Sayed, S.G. and Ismail, S.M. (2017). Influence of bio and chemical fertilization on croton production, Assiut J. Agric. Sci., 48(3):112-122.

Ghatas, Y.A.A. (2015). Response of Hemerocallis aurantiaca plants to kinetin and chemical fertilization treatments. Middle East J. Agric. Res., 4(4):650-659.

Ghatas, Y.A.A. (2016). Effect of GA3 and chemical fertilization treatments on growth, flowering, corm production and chemical composition of Gladiolus grandiflorus plant. J. Plant Production, Mansoura Univ., 7(6):627-636.

Ghatas, Y.A.A. (2020). Impacts of using some fertilization treatments in presence of salicylic acid foliar spray on growth and productivity of Coriandrum sativum L. Plant. J. Plant Production, Mansoura Univ., 11(2):119-125.

Ghatas, Y.A.A. and Abdallah, W.H. (2016). Effect of some fertilization and micro nutrients treatments on growth and chemical constituents of Echinacea purpurea plant. J. Plant Production, Mansoura Univ., 7(7):709-719.

Graf, A.B. (1992). Hortica: Color Cyclopedia of Garden Flora and Indoor Plants . $1^{\text {st }}$ ed. Roehs Company Puplisher. U.S.A., 1216 p.
Gut, B. (2008). Trees in Patagonia. Springer Science \& Business Media, Basil, Switzerland, 263 p.

Habib, A. (2012). Effect of NPK and growing media on growth and chemical composition of fishtail palm (Caryota mitis Lour). Life Science Journal, 9(4):3159- 3168.

Hamad, I.A. (2020). Physiological Studies on Aspidistra elatior L. Plant. M.Sc., Thesis, Fac. Agric., Benha Univ., Egypt, $83 \mathrm{p}$.

Hassan, E.A. and El-Quesni, F.M. (1989). Application of growth regulators in agriculture, A cytokinin induced new morphogenetic phenomena in carnation (Dianthus caryophyllus L). Bull. Fac. Agric, Cairo Univ., 40:187-196.

Hegazy, T.A.M. (2000). Physiological Studies on Gladiolus Plant. M.Sc. Thesis, Fac. Agric., Minufiya Univ., Egypt, 157 p.

Herbert, D.; Phipps, P.J. and Strange, R.E. (1971). Determination of total carbohydrates, Methods in Microbiology, 5 (8): 290-344.

Hogan, C.M. and Frankis, M.P. (2009). Monterey Cypress, Cupressus macrocarpa, Global Twitcher.com, ed. N. Stromberg.

Hopkins, W. and Huner, N.P.A. (2008). Introduction to Plant Physiology $4^{\text {th }}$ ed. John Wiley and Sons, U.S.A., 523 p.

Horneck, D.A. and Hanson, D. (1998). Determination of potassium and sodium by flame emission spectrophotometry. In: Kolra, Y.P. (ed.), Handbook of Reference Methods for Plant Analysis, pp. 153-155.

Horneck, D.A. and Miller, R.O. (1998). Determination of total nitrogen in plant. In: Kolra, Y.P. (ed.), Handbook of Reference Methods for Plant Analysis, Taylor and Francis Group. LLC., 73 p.

Hucker, T. and Catroux, G. (1980). Phosphorus in sewage ridge and animal's wastes slurries. Proceeding of the EEC 
Seminar, Haren (Gr): Gromingen Netherlands, 12-13 June.

Hussein, M.M.M. (2009). Effect of giberellic acid and chemical fertilizers on growth and chemical composition of Cryptostegia grandiflora, R. Br. Plants. T. Hort. Sci. \& Ornamental Plants, 1(2):27-38.

Ibrahim, S. M.M.; Taha, L.S. and Farahat, M.M. (2010). Vegetative growth and chemical constituents of croton plants as affected by foliar application of benzyladenine and gibberellic acid. Journal of American Science, 6(7):126130.

Kashif, M.; Rizwan, K.; Khan, M.A. and Younis, A. (2014). Efficacy of macro and micro-nutrients as foliar application on growth and yield of Dahlia hybrida L. (Fresco). Int. J. Chem. Bioch. Sci., 5:610.

Kenneth, V.T. (1979). Physiology of Plant Growth and Development. Nalcolm. B. Wilkins TATA McGraw-Hill Publishing Co. Ltd. New-Delhi., 570 p.

Kulaeva, O.N. (1979). Cytokinin action on enzyme activities in plants. In: Skoog, F. (ed.), Plant Growth Substances, Springerverlage, Berlin, Heidelberg, New York, pp. 119-128.

Leopol, A.C. and Kawase M. (1964). Senescence of a trifoliate bean leaf caused by treating the primary leaves of cuttings with benzyladenine. Amer. J. Bot., 51:294-298.

Lumis, G.; Purvis, P. and Taurins, L. (2000). Flood irrigation of container grown Euonymus and Thuja as affected by fertilizer rate and substrate. J. Environ. Hort., 18(1):13-17.

Majidian, N.; Nadari, A. and Majidian, M. (2012). The effect of four levels of GA3 and BA on the quantitative and qualitative characteristics of Zantedeschia aethiopica cv. Childsiana Pot Plant. Journal of Horticultural Science, 25(4):361-368.
Manasa, M.D.; Chandrashekar, S.Y.; Hanumantharaya, L.; Ganapathi, M. and Hemanth, K.P. (2017). Influence of growth regulators on vegetative parameters of gladiolus cv. Summer Sunshine. Int. J. Curr. Microbiol. App. Sci., 6(11):1299-1303.

Marschner, H. (1997). Mineral Nutrition of Higher Plants. Second Printing, Academic Press Inc., San Diego, 889 p.

Matin, S.; Mortazawi, S. and Heidari, M. (2015). Application of benzyladenine and potassium nitrate on growth, nitrate content and nitrate reductase activity in Narcissus tazetta. Environmental Biology, 9(6):824-830.

Maximoos, S.L. (1993). Physiological and Hormonal Studies on The Growth and Flowering of Gerbera Plant. Ph.D. Thesis, Fac. Agric., Ain Shams Univ., Egypt, 417 p.

Mazhar, A.A.M. and Eid, R.A. (2016). Effect of various doses of chemical fertilizer (kristalon) individually or in combination with different rates of biofertilizer on growth, flowering, corms yield and chemical constituents of Gladiolus grandifloras. International Journal of PharmTech Research, 9(12):139-145.

Mohamed, Y.F.Y. (2018). Influence of different growing media and kristalon chemical fertilizer on growth and chemical composition of areca palm (Dypsis cabadae H.E. Moore) plant. Middle East J. Appl. Sci., 8(1):43-56.

Mostafa, G.A.A. (2018). Effect of Planting Media and Fertilization on Growth and Chemical Composition of Areca Plant. M.Sc. Thesis, Fac. Agric., Benha Univ., Egypt, 98 p.

Nambiar, N.; Siang, T.C. and Mahmood, M. (2012). Effect of 6-benzylaminopurine on flowering of a Dendrobium orchid. A.J.C.S., 6:225-231.

Pal, A.K. and Biswas, B. (2005). Effect of fertilizer on growth and yield of tuberose 
(Polianthes tuberosa L.) cv. Calacutta Single in the plains of West Bengle. J. Interacademicia, Nadia, India, 9(1):3336.

Raghothama, K.G. (1999). Phosphate Acquisition, Annu. Rev. Plant Physiology and Plant Molecular Biology, 50:665-693.

Ramtin, A.; Kalatejari, S.; Naderi, R. and Matinizadeh, M. (2016). Effect of benzyladenine and salicylic acid on biochemical traits of two cultivars of carnation. Journal of Experimental Biology and Agricultural Sciences., 4 (4):427-434.

Reza, R.R.; Wardanif, F. and Zulkarnaen, R.N. (2017). The effect of NPK fertilizer and planting media on plant growth and saponin content of the medicinal plant Anchomanes difformis. Nusantara Bioscience, 9(2):141-145.

Rodrigo, A.C.; Bonello, P. and Herms, D.A. (2011). Effect of the growth regulator paclobutrazol and fertilization on defensive chemistry and herbivore resistance of Austrian pine (Pinus nigra) and paper birch (Betula papyrifera.). Arboriculture \& Urban Forestry, 37(6): 278-287.

Runkle, E. (2006). Recovering from a PGR overdose. In Greenhouse Product News. 16(9):78.

Sajjad, Y.; Jaskani, M.J.; Asif, M. and Qasim, M. (2017). Application of plant growth regulators in ornamental plants: A review. Pakistan Journal of Agricultural Sciences, 54(2):327-333.

Sajjad, Y.; Jaskani, M.J.; Qasim, M.; Mehmood. A.; Ahmad. N. and Akhtar, G. (2015). Pre-plant soaking of corms in growth regulators influences the multiple sprouting, floral and corm associated traits in Gladiolus grandifloras L. J. Agric. Sci., 7(9):173-181.

Salehi Sardoei, A. (2014). Gibberellic acid and benzyladenine application increase offsets in Aloe barbadensis. Eur. J. Exp. Biol., 4(1):646-650.

Salisbury, F.B. and Ross, C.W. (1974). Plant Physiology, $2^{\text {nd }}$ ed. Publishing Inc. Belmont, California, 422 p.

Shudok, K. (1994). Chemistry of phenylurea cytokinins. In: Mokk, D.V. and Mc Mok (eds.), Cytokinins: Chemistry, Activity and Function, CRC Press, Boca Raton., pp. 35-42.

Singh, W.; Sehrawat, S.K.; Dahiya, D.S. and Singh, K. (2002). Leaf nutrient status of gladiolus (Gladiolus grandiflorus L.) cv. Sylvia as affected by NPK application. Haryana Journal of Horticultural Sciences, 31(1/2):49-51.

Snedecor, G.W. and Cochran, W.G. (1989). Statistical methods, $8^{\text {th }}$ ed., Iowa State Univ. Press, Iowa, U.S.A., 503 p.

Sorour, M.A. and El-Shanhorey, N.A. (2016). Effect of foliar applied benzyladenine and gibberellic acid on vegetative growth and chemical constituents of Dracaena marginata (B.) pinched plants. J. Adv. Agric. Res. 21(1): 84-95.

Stiles, W. (2006). Principles of Plant Physiology. Discovery Publishing House, New Delhi, India, 593 p.

Taiz, L. and Zeiger, E. (2002). Plant Physiology, $3^{\text {rd }}$ ed. Sunderland: Sinauer Associates, $690 \mathrm{p}$.

Taiz, L. and Zeiger, E. (2010). Plant Physiology. $5^{\text {th }}$ ed. Sunderland: Sinauer Associates, $692 \mathrm{p}$.

Thukral, S.K.; Sumitra, S. and Surendra, K.S. (2014). Pharmacognostical standardization of leaves of Cupressus macrocarpa Hartweg. ex Gordon. J. Appl. Pharm. Sci., 4:71-74.

Vijayakumari, B. (2002). Influence of foliar spray by GA3 and IAA on the growth attributes of Andrographis paniculata L. Journal of Phytological Research Physiological Society, 12:161-163. 
Wanderley, C.S.; Faria, R.T. and Ventura, M.U. (2012). Chemical fertilization, organic fertilization and pyroligneous extract in the development of seedlings of areca bamboo palm (Dypsis lutescens). Maringá, 34(2):163-167.

Younis, A.; Riaz, A.; Khosa, S.S.; Rayit, A. and Yasmeen, S. (2011). Effect of foliar application of macro and micro nutrients on growth and flowering of Gerbera jamesonii L. American-Eurasian J. Agric. Environ. Sci., 11:736-757.

Younis, S.I.; Moustafa, S.M. and Menesy, F.A. (2004). Effect of different fertilization treatments on Jasminum grandiflorum, L. J. Agric. Res., 30(1):97113.

Youssef, A.S.M. (2014). Effect of different growing media and chemical fertilization on growth and chemical composition of ponytail palm (Beaucarnea recurvata) plant. Annals of Agric. Sci., Moshtohor, 52(1):27-38.

Youssef, A.S.M. and Abd El-Aal, M.M.M (2014). Effect of kinetin and mineral fertilization on growth, flowering, bulbs productivity, chemical composition and histological features of Hippeastrum vittatum plant. J. Plant Production, Mansoura Univ., 3:357-371.

Youssef, A.S.M. and Mady, M.A. (2013). Influence of light intensity and benzyladenine on growth performance of Aspidistra elatior Blume plant, Res. J. Agric. \& Biol. Sci., 9(5):248-257.

\section{تاثير معاملات البنزايل آدنين وسماد الكريستالون علي النمو والمحتوي الكيماوي لنبات السرو الليموني}

$$
\text { قسم البساتين، كليه الفتاح عبد العاطى غطاس جامعة بنها، مصر }
$$

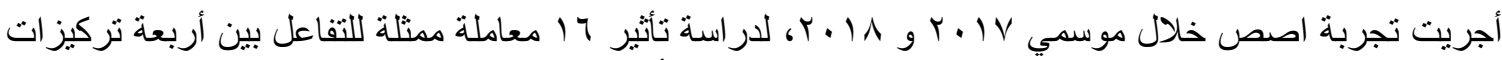

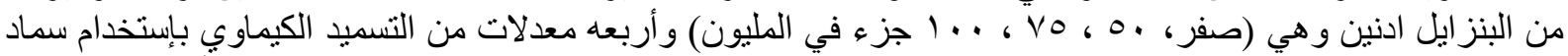

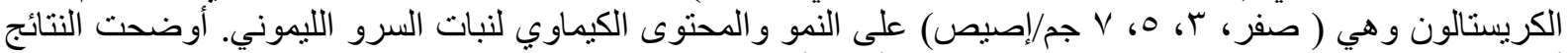

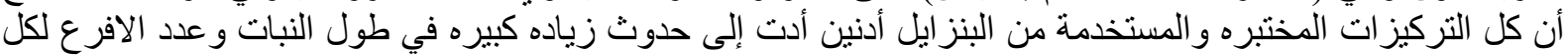

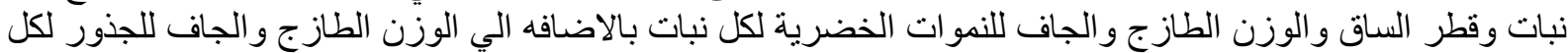

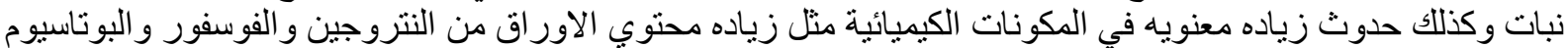

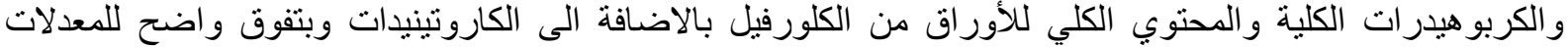

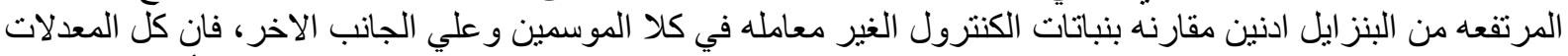

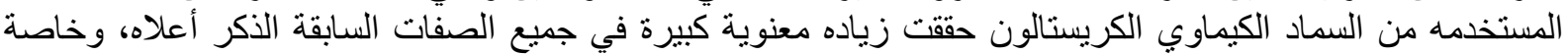

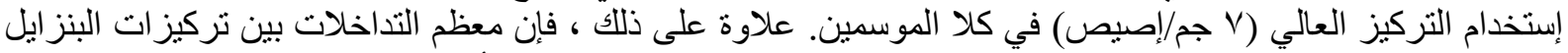

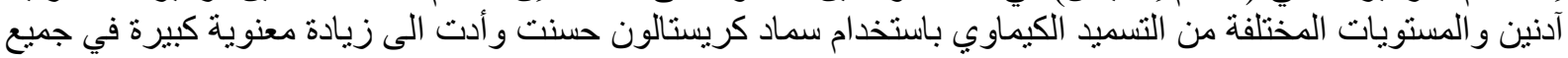

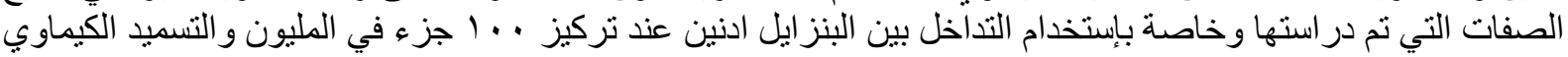

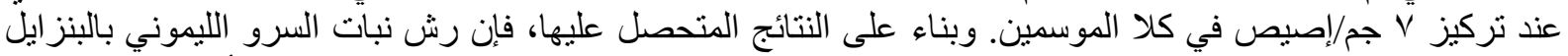

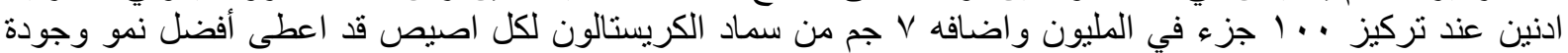
لنبات السرو الليموني. 